\title{
Analyzing Pedagogical Content Knowledge of Algebra using Confirmatory Factor Analysis
}

\author{
Siti Mistima Maat ${ }^{1 *}$ and Effandi Zakaria ${ }^{2}$ \\ 'Universiti Kuala Lumpur Malaysia France Institute; mistima@mfi.unikl.edu.my \\ 2Faculty of Education, UniversitiKebangsaan Malaysia, Bangi, Selangor; effandi@ukm.my
}

\begin{abstract}
This study was conducted to analyze pedagogical content knowledge of secondary school teachers. A total of 254 mathematics school teachers from various secondary schools in Negeri Sembilan were randomly selected to participate in the study. A set of multiple choice questions were given to teachers during the data collection process. The questions were developed by the researcher. Confirmatory Factor Analysis (CFA) was used to validate the instrument. A good model fit was found for measurement model of pedagogical content knowledge using several fit index tests including CMINDF, GFI, CFI, TLI, and RMSEA. The findings revealed that the subject content knowledge and knowledge of students has a stronger covariance value than the subject content knowledge and knowledge of pedagogy and a stronger covariance between knowledge of students and knowledge of pedagogy. Teachers should be able to recognize their type of knowledge, particularly pedagogical content knowledge to transfer their knowledge effectively to the students.
\end{abstract}

Keywords: Mathematics Teachers, Students' Knowledge, Algebra, Quadratic Function, Secondary School Teaching

\section{Introduction}

At the early stage of teacher education, knowledge of teaching is important to ensure that teachers can teach effectively. The notion of knowledge has become a growing interest among educators and researchers since Shulman ${ }^{1}$ introduced the notion of pedagogical content knowledge. The intersection between knowledge of pedagogy and knowledge of content reflects the definition of what pedagogical content knowledge is all about. In brief, Shulman proposes that the component of pedagogical content knowledge consist of knowledge of subject, knowledge of teaching, and knowledge of curriculum. As such, teachers should have knowledge on how to represent and formulate the subject of study to increase their students' understanding. Knowledge of content refers to knowledge of the subject; in this study the focus is on mathematics and its content structure. In addition, knowledge of students is also included in pedagogical content knowledge because it relates to knowledge of teaching and knowledge of pedagogy ${ }^{3}$.

Grossman $^{2}$ stated that pedagogical content knowledge includes knowledge of content, knowledge of pedagogy, and knowledge of context. These different types of knowledge can be obtained from class observations, formal education, and teaching experience. Ball and Bass defined pedagogical content knowledge as a practical knowledge of teaching that distinguishes the characteristics of the subject content expert and pedagogical expert Elias ${ }^{4}$. However, discussion on the component of knowledge is not limited to what has been suggested by the previous researchers. The research on pedagogical content knowledge has been conducted using different approaches, which have been discussed in various aspects ${ }^{5}$. Most previous studies have been conducted using a qualitative

${ }^{*}$ Author for correspondence 
approach and only a few cases of quantitative research have been conducted (e.g., Elias ${ }^{4}$; Aida Suraya ${ }^{6}$. The aim of Habibah et al. (2005) was to identify the acceptance of 26 teachers towards pedagogical content knowledge, and was based on Shulman's model. Using a quantitative approach, Aida ${ }^{6}$ reported that the mean score of pedagogical content knowledge of 268 trainee teachers from five public universities was at an acceptable level. However, the purpose of this study was to validate the instrument using confirmatory factor analysis for pedagogical content knowledge of mathematics teachers in algebra.

\section{Methodology}

A total of 254 mathematics teachers from secondary schools in Negeri Sembilan were chosen to using stratified random sampling. As shown in Table 1, most teachers were female (79.9\%); $20.1 \%$ of the sample were male teachers. Additionally, $81.9 \%$ were Malays, $27 \%$ were Chinese, $6.7 \%$ were Indian and the rest were from other race. As for teaching experience, 124 (48.8\%) teachers had more than 10 years experience and $22(8.7 \%)$ had between 3 to 5 years of teaching experience.

Teachers were given a set of multiple-choice questions that consisted of 11 questions on quadratic functions and quadratic equations. The questions were based on Kovarick $^{7}$, Shuhua ${ }^{8}$ and Black ${ }^{9}$ findings. The number of question for each knowledge component of pedagogical content knowledge is shown in Table 2. The development of the multiple-choice question was done in three stages. In brief, the first stage included gathering responses from 51 mathematic teachers. Next, the answers were grouped accordingly and validated using experts to ensure that the grouping of answers was done correctly. There were five categories, labelled A, B, C, D, and E, with marks that ranged from 1 to 5 , respectively. The rubric of these categories were based on the PCK rubric of Tengku Zawawi ${ }^{10}$ and Park ${ }^{11}$. The reliability index ${ }^{12}$ refers to the degree of agreement of the marks for each category; in this study, the reliability index was $87.8 \%$. During the second stage, the questions were distributed to 101 secondary mathematics teachers with the intention of determining the reliability of the questions. The Cronbach's Alpha was 0.78 . However, the reliability value of each construct ranged from 0.43 to 0.58 . Although the value was considered low, it increased when the researcher calculated
Table 1. Respondent profile

\begin{tabular}{lcccc}
\hline Type & N & Factor & Frequency & $\begin{array}{c}\text { Percentage } \\
(\%)\end{array}$ \\
\hline Gender & 254 & Male & 51 & 20.1 \\
& & Female & 203 & 79.9 \\
Race & \multirow{2}{*}{254} & Malay & 208 & 81.9 \\
& & Chinese & 27 & 10.6 \\
& & Indian & 17 & 6.7 \\
& & Others & 2 & 0.8 \\
Years of & \multirow{2}{*}{254} & 1-3 years & 48 & 18.9 \\
experience & & 3-5 years & 22 & 8.7 \\
& & 5-10 years & 60 & 23.6 \\
& & $>10$ years & 124 & 48.8 \\
\hline
\end{tabular}

Table 2. Number of question per component in PCK

\begin{tabular}{lc}
\hline Component of PCK & $\begin{array}{c}\text { Number of question } \\
\text { (item) }\end{array}$ \\
\hline Knowledge of subject content & 4 \\
Knowledge of students & 4 \\
Knowledge of pedagogy & 3 \\
\hline
\end{tabular}

the construct reliability and variance extracted upon the completion of confirmatory factor analysis.

After some modification to the questions, the next stage was data collection process that involved 254 mathematics teachers. Data were entered into SPSS version 16.0 and a confirmatory factor analysis was performed by AMOS version 16.0.

\section{Results}

The data were analysed using SPSS 16.0 and AMOS 16.0. A confirmatory factor analysis was used to validate the measurement model of pedagogical content knowledge with three factors that included knowledge of subject content (four items), knowledge of pedagogy (three items), and knowledge of students (four items). At the beginning stage of the analysis, one item from knowledge of subject content was omitted because it had a factor loading of less than 0.40. Fit index tests including the traditional chi-square test, the relative chi-square (CMINDF: the Chi-Square/Degree of Freedom), Tucker Lewis Index (TLI), Comparative Fit Index (CFI), Goodness 
of Fit Index (GFI), and Root Mean Square of Error Approximation (RMSEA) were used to test model fit. The model fit can be obtained when all conditions of the fit indices are fulfilled. The value of the relative Chi-Square must be within 1 and 5; TLI, GFI, and CFI values must exceed 0.90; and RMSEA should be less than $0.08^{13}$.

The analysis revealed the following: $\mathrm{CMIN} / \mathrm{DF}=$ 2.159; $\mathrm{GFI}=.949 ; \mathrm{TLI}=.900 ; \mathrm{CFI}=.936$; and RMSEA $=$ .068. The fit index value indicated that the model fit was acceptable. Figure 1 shows the finalized measurement model for pedagogical content knowledge with three structures. Each observed variable, represented by box has an acceptable significant factor loading. The covariance, which could be interpreted as a correlation ${ }^{14}$, shows significant value between knowledge of subject content and knowledge of pedagogy and knowledge of students. The covariance between knowledge of subject content and knowledge of students was 0.89 and significant at $p<0.001$. This value was greater than the covariance between knowledge of subject content and knowledge pedagogy and the covariance between knowledge of students and knowledge of pedagogy. Each construct of pedagogical content knowledge produced an acceptable value of construct reliability and variance extracted. The values of construct reliability for knowledge of subject content, knowledge of students, and knowledge of pedagogy was $0.63,0.70$, and 0.83 respectively. The value of variance extracted for all constructs was within 0.50 to 0.62. Pedagogical content knowledge produced a value of 0.90 for construct reliability and 0.62 for the variance extracted value.

\section{Discussion}

The measurement model of pedagogical content knowledge in this study was limited to knowledge of subject content, knowledge of pedagogy, and knowledge of students. Based on the fit indices of CMINDIF, TLI, GFI, RMR, and RMSEA, the confirmatory factor analysis showed that model fit was achieved. Because most research in pedagogical content knowledge have been

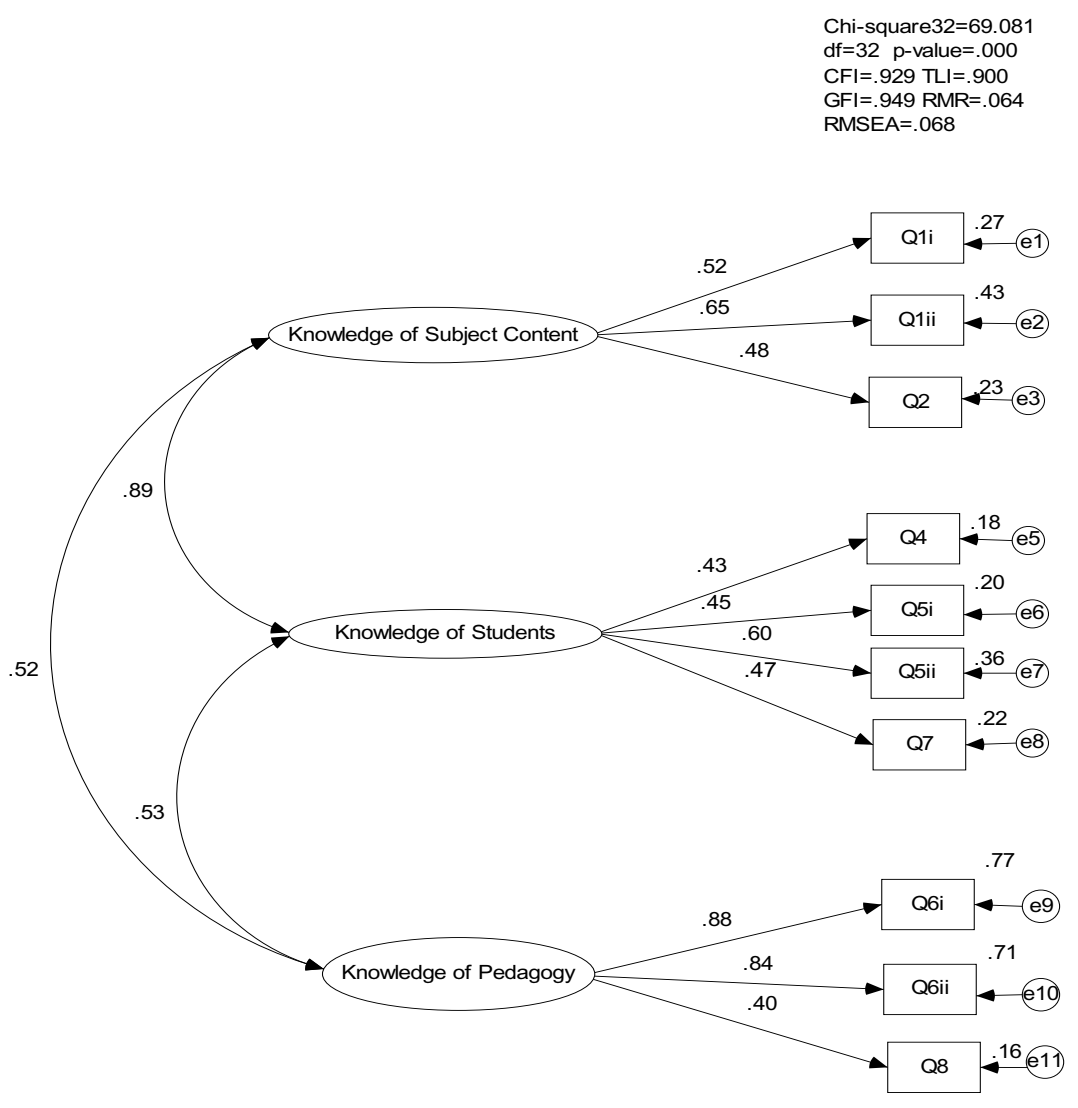

Figure 1. The finalized measurement model of teachers PCK. 
conducted using a qualitative approach ${ }^{15,16}$, the findings of this study contribute to the body of knowledge particularly with respect to validating the measurement of pedagogical content knowledge.

As shown in Figure 1, the covariance value between knowledge of subject content and knowledge of students indicates a stronger relationship than the covariance between knowledge of students and knowledge of pedagogy. The high value between the two types of knowledge is probably due to the teacher's mastery of algebra, which mainly focuses on quadratic functions and quadratic equations. These topics have been learnt since secondary school and teachers are expected to have the skill in delivering the content of such topics. This finding is consistent with what has been reported by Park ${ }^{17}$. He finds that knowledge of subject content and knowledge of students are better than the knowledge of pedagogy. However, the study focuses on the comparison of pedagogical content knowledge in fraction using the qualitative approach. Having good knowledge of subject content influences teachers' knowledge of their student that could be used to identify the students' ability. The knowledge should be delivered according to students' level ${ }^{17}$.

The moderate covariance value between knowledge of subject content with knowledge of pedagogy may occur due to inconsistencies between the knowledge possessed and the way content is delivered. Although these teachers have mastered the topic well, they may also face difficulty in selecting effective strategies to enhance students' understanding. Teachers may have to repeat their teaching when students demonstrate poor performance ${ }^{10}$.

The moderate covariance value between knowledge of students and knowledge of pedagogy may occur due to lack of teachers' attention to students' basic knowledge, and misconceptions as well as insensitivities to the difficulty level of subject content ${ }^{18}$. Teachers often refer to their teaching manual during the early stages of their teaching career. However, they should expand their knowledge, which is bound to their professional knowledge and modifications should be made to match their students' ability ${ }^{19}$.

\section{Conclusion}

Without proper knowledge, teachers will face difficulty in achieving success. Teachers should be able to identify the type of knowledge they possess to suit the diversity of knowledge their students posses. Teachers are expected to experience growth of their existing knowledge, especially pedagogical content knowledge so that the knowledge can be transferred effectively to students'. Additionally, they should be able to connect existing knowledge to other mathematical topics ${ }^{9}$, which will help them enhance their conceptual knowledge of any given topic. Teachers may have more procedural knowledge than conceptual knowledge or pedagogical content knowledge, but lack a deep understanding of the said knowledge that will impact to their teaching. As such, pedagogical content knowledge could be considered in how teachers act on their knowledge and how that knowledge could be conveyed to students ${ }^{20}$. To be proficient in teaching, preparing teachers as early as possible should be considered; for example, teaching practice during their pre-service training. Past experience also plays an important role in developing such knowledge before they go to school to start their careers.

It is suggested that further studies should be conducted on the aspect of pedagogical content knowledge particularly using the quantitative approach in measuring pedagogical content knowledge. Some consideration in validating the measurement and testing the questions in a different context are highly recommended for future study.

\section{References}

1. Shulman LS. Knowledge and teaching: foundation of the new reform. Harv Educ Rev. 1987 Feb; 57(1):1-22.

2. Grossman PL. The making of a teacher: teacher knowledge and teacher education 1st ed. New York: Teachers College Press; 1990.

3. Turnuklu EB, Yesildere S. The pedagogical content knowledge in mathematics: preservice primary mathematics teachers' perspective in Turkey. IUMPST: The Journal. 2007 Oct; $1: 1-13$.

4. Elias H, Lope ZA, Mahyudin R. Competencies Needed by Teachers: Implication for Best Teaching Practices. Serdang: Universiti Putra Malaysia Press; 2005.

5. Van Driel JH, Van Jong O, Verloop N. The development of preservice chemistry teachers' PCK. Sci Educ. 2002 Jul; 86(4):572-590.

6. Md Yunus AD, Hamzah R, Ismail H. Mathematics teachers' preparation program: determining the balance between contents in Mathematics and pedagogy. European Journal of Social Sciences. 2008; 6(4):125-31. 
7. Kovarick K. Mathematics educators' and teacher's perceptions of pedagogical content knowldege [Doctoral dissertation]. University of Columbia; 2008.

8. Shuhua A, Kulm G, Zhonghe W. The pedagogical content knowledge of middle school, mathematics teachers in China and the U.S. Journal of Mathematics Teachers Education. 2004; 7(2):145-72.

9. Black WDJ. The relationship of teachers' content knowledge and pedagogical content knowledge in algebra, and changes in both types of knowledge as a result of professional development [Doctoral dissertation]. University of Auburn; 2007.

10. Tengku Z. Pengetahuan pedagogi isi kandungan bagi tajuk pecahan di kalangan guru matematik sekolah rendah (Pedagogical content knowledge of fraction among mathematics primary school teachers) [Doctoral dissertation]. Malaysia: Department of Education, Universiti Kebangsaan; 2005.

11. Park S, Chen Y-C, Jang J. Developing measures of teachers' pedagogical content knowledge for teaching high school biology. International conference of the Association for Science Teacher Education; 2008 Jan; St. Louis, Missouri; 2008.

12. Miles MB, Huberman AM. An expanded sourcebook: qualitative data analysis Ed.ke-2. Thousand Oaks: Sage Publications; 1994.

13. Schumacker RE, Lomax RG. A beginner's guide to structural equation modeling. NJ: Lawrence Erlbaum Associates; 2004.
14. Hair JF, Anderson RE, Tatham RL, Black WC. Multivariate Data analysis. 7th ed. NJ: Prentice-Hall; 2010.

15. Yazid Z. Pengetahuan pedagogikal kandungan (PPK) Guru Matematik Tambahan Berpengalaman. [Tesis Dr.Fal]. Universiti Kebangsaan Malaysia, Bangi; 2005.

16. Saad NS. Pengetahuan Pedagogi Kandungan dan Amalannya di Kalangan Guru Matematik Sekolah Menengah (Pedagogical Content Knowledge and Practices among Secondary Schools Teachers). [PhD Thesis]. Universiti Perguruan Sultan Idris; 2006.

17. Park S, Oliver JS. Revising the conceptualization of Pedagogical Content Knowledge (PCK): PCK as a conceptual tool to understand teachers as profesionals. Research Science Education. 2008; 38:261-84.

18. Halim L, Mohd Meerah ST. Science trainee teachers' pedagogical content knowledge and its influence on physics teaching. Research in Science and Technological Education. 2002; 20(2):215-25.

19. Barret D, Green K. Pedagogical content knowledge as a foundation for an interdisciplinary graduate program. Sci Educ. 2009; 18(1):17-28.

20. Abd-El-Khalick F. Preservice and experienced biology teachers global and specific subject matter structures: implications for conceptions of pedagogical content knowlegde. Eurasia J Math Sci Tech Ed. 2006; 2(1):1-29. 